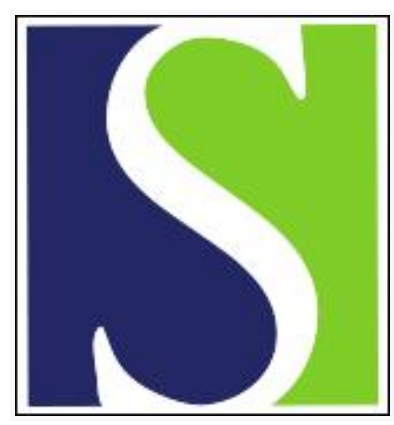

Scand J Work Environ Health 1993;19(2):115-120

https://doi.org/10.5271/sjweh.1498

Issue date: 01 Apr 1993

Pulmonary function one and four years after a deep saturation dive.

by Thorsen E, Segadal K, Kambestad BK, Gulsvik A

Affiliation: Norwegian Underwater Technology Centre A/S, Ytre Laksevag.

This article in PubMed: www.ncbi.nlm.nih.gov/pubmed/8316778

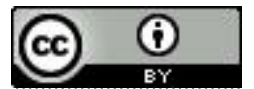




\title{
Pulmonary function one and four years after a deep saturation dive
}

\author{
by Einar Thorsen MD, ${ }^{1}$ Kåre Segadal MSc, ${ }^{1}$ Brit K Kambestad MSc, ${ }^{1}$ Amund Gulsvik MD²
}

\begin{abstract}
THORSEN E, SEGADAL K, KAMBESTAD BK, GULSVIK A. Pulmonary function one and four years after a deep saturation dive. Scand $J$ Work Environ Health 1993;19:115-20. The pulmonary function of 24 Norwegian divers who had participated in a deep saturation dive to pressures of 3.1 4.6 MPa was reevaluated one and four years later. Twenty-eight divers performing ordinary saturation diving to pressures of $0.8-1.6 \mathrm{MPa}$ and followed over a three-year period served as referents. A significant reduction in forced expiratory volume in $1 \mathrm{~s}\left(\mathrm{FEV}_{1.0}\right)$ of $210(\mathrm{SD} 84) \mathrm{ml}(\mathrm{P}<0.001)$ occurred the first year after the dive. Thereafter the annual reduction in FEV 1.0 was 28 (SD 62) $\mathrm{ml}$. year ${ }^{-1}$; this value did not differ from the 35 (SD 80) $\mathrm{ml} \cdot$ year $^{-1}$ of the referents. The forced midexpiratory flow rate and forced expiratory flow rates at low lung volumes were also significantly reduced one year after the deep dive, and the closing volume was increased. No significant changes occurred in forced vital capacity. The results agree with those of cross-sectional studies on divers' lung function and indicate the development of airflow limitation in relation to diving exposure.
\end{abstract}

Key terms: diving, lung function, occupational exposure.

Diving operations are necessary for the installation and maintenance of the oil and gas production and transport systems in the North Sea at depths of 50$360 \mathrm{~m}$, corresponding to pressures of $0.6-3.7 \mathrm{MPa}$. Saturation diving is the method used to dive to such depths. The divers are compressed to the pressure corresponding to the working depth in a hyperbaric chamber complex, where they live at increased pressure for periods of up to four weeks. They are transferred to the in-water worksite in a diving bell. There can be as many as 16 divers living in the hyperbaric chamber complex at the same time. With this diving method all tissues are saturated with the inert gas of the atmosphere, and therefore the available bottom time is not limited as in surface-oriented diving or bounce diving. The rate of decompression is, however, limited by the rate of inert gas washout from the tissues. If decompression sickness is to be avoided, the mean rate of decompression must be $10-12.5 \mathrm{kPa} \cdot \mathrm{h}^{-1}$ or $0.24-0.30 \mathrm{MPa} \cdot \mathrm{d}^{-1}$. The inert gas of the atmosphere is usually helium to reduce the density of the breathing gas and thereby the work of breathing. The partial pressure of oxygen is raised to $35-40 \mathrm{kPa}$ during the isopression phase of the dive, to ensure oxygenation, and to $50-60 \mathrm{kPa}$ during the decompression phase, to facilitate inert gas elimination.

\footnotetext{
1 Norwegian Underwater Technology Centre A/S, Ytre Laksevăg, Norway.

2 Department of Thoracic Medicine, University of Bergen, Bergen, Norway.
}

Reprint requests to: Dr E Thorsen, NUTEC, PO Box 6, N5034 Ytre Laksevåg, Norway.
Cross-sectional studies of divers' lung function indicate the development of airflow limitation in relation to diving exposure $(1-4)$. Their lung function is, however, also influenced by the effects of adaptation to the hyperbaric environment with increased gas density, which would result in an increase in forced vital capacity (FVC) but not in forced expiratory volume in $1 \mathrm{~s}\left(\mathrm{FEV}_{10}\right)$, giving a low $\mathrm{FEV}_{1.0}$ : FVC ratio (5-7). The selection of subjects as divers could also result in a group of very fit subjects with these lung function characteristics, as there is a negative relationship between FVC and the $\mathrm{FEV}_{1.0}: \mathrm{FVC}$ ratio $(1,8)$.

To study the course of lung function changes in professional saturation divers, a longitudinal followup of pulmonary function was made of a group of professional Norwegian divers who had participated in a deep experimental saturation dive to pressures of 3.1 4.6 MPa. This group of deep divers was compared with a group of divers performing ordinary saturation diving in the North Sea to pressures of $0.8-1.6 \mathrm{MPa}$.

\section{Subjects and methods}

Forty-three professional saturation divers participated in eight different deep saturation dives in Norway in 1983-1986. The maximal pressures were 3.1-4.6 $\mathrm{MPa}$, equivalent to sea water depths of $300-450 \mathrm{~m}$, and there were four to nine divers participating in each dive. The characteristics of the dives and the acute effects of the dives on pulmonary function have been described elsewhere $(9,10)$. Of the 43 divers, 24 were Norwegians. The Norwegian divers were all reexamined one year after the deep dive, and 22 of 
them were available for another examination 4.0 (SD 1.0) years after the deep dive. Their base-line anthropometric data, smoking habits, and diving experience are shown in table 1. Ex-smokers were classified as nonsmokers if they had stopped smoking more than one year earlier; otherwise they were considered smokers. Three divers had participated in a deep dive to pressures of 3.1 and $5.1 \mathrm{MPa}$ one and four years before entry into this study.

The deep divers were compared with 28 professional saturation divers who did not participate in deep dives (reference divers), but who performed ordinary saturation diving in the North Sea to pressures of 0.8-1.6 MPa. They were divers who had attended the Norwegian Underwater Technology Centre for their annual medical certification and who had at least two examinations one year or more apart during the period 1983-1990. The mean observation time was 3.0 (SD 0.9) years. Their base-line anthropometric data, smoking habits, and diving experience are shown in table 1 . This group of divers was not significantly different from the group of deep divers with respect to previous diving experience and base-line pulmonary function. Both groups had a reduced forced midexpiratory flow rate $\left(\mathrm{FEF}_{25-75}\right)$ and reduced maximal flow rates at low lung volumes $\left(\mathrm{FEF}_{75-85}, \mathrm{FEF}_{50}, \mathrm{FEF}_{75}\right)$, consistent with the characteristics of divers' lung function in general $(1-4)$.

There were no significant differences in age, height, weight, smoking habits (table 1), or in initial pulmonary function (table 2 ) between the deep divers and the referents at the time of entry into the study. The control divers were all, except two, active in operational diving in the North Sea throughout the observation period, and their median time in saturation dives was 38 (range 12-64) d each year at maximal pressures of $0.8-1.6 \mathrm{MPa}$. The divers who were not active had advanced to diving supervisors during the observation period. Three of the deep divers had stopped diving after the deep dive for reasons not related to their pulmonary function, and three had advanced to diving supervisors during the follow-up period. The others were still active in operational diving in the North Sea, and their median time in saturation dives after the deep dive was 27 (range 16-60) d each year at maximal pressures of $0.8-1.6 \mathrm{MPa}$. Regular diving in the North Sea was resumed three to six months after the deep dive. The diving exposures, measured as cumulative hyperoxic exposure, cumulative hyperbaric exposure, days in saturation, and days in decompression, were all interrelated and correlated significantly with the maximal pressure to which they were exposed (correlation coefficient $0.7-0.9, \mathrm{P}<0.01$ ).

On every occasion the subjects were given a structured interview registering pulmonary symptoms and diving exposure. Diving exposure was registered as the number of saturation dives between the observations with the registration of the pressure and duration of the dives partitioned into days in compression, isopression, and decompression. In the operational diving in the North Sea, as well as in the deep saturation dives, modified saturation decompression tables of the United States Navy were used with rates of decompression of $0.24-0.30 \mathrm{MPa} \cdot \mathrm{d}^{-1}$, and partial pressures of oxygen of $40 \mathrm{kPa}$ during the isopression and $50 \mathrm{kPa}$ during the decompression phases. The cumulative hyperoxic and cumulative hyperbaric exposures were calculated for each diver during the observation period.

Table 1. Base-line anthropometric data and diving experience of the deep divers and referents at the time of entry into the study.

\begin{tabular}{|c|c|c|c|c|c|c|c|c|c|c|c|c|}
\hline \multirow[t]{2}{*}{ Group } & \multicolumn{2}{|c|}{$\begin{array}{c}\text { Age } \\
\text { (years) }\end{array}$} & \multirow{2}{*}{$\begin{array}{c}\begin{array}{c}\text { Height } \\
(\mathrm{cm})\end{array} \\
\text { Mean SD }\end{array}$} & \multirow{2}{*}{\multicolumn{2}{|c|}{$\begin{array}{c}\begin{array}{c}\text { Weight } \\
(\mathrm{kg})\end{array} \\
\text { Mean SD }\end{array}$}} & \multirow{2}{*}{$\begin{array}{c}\text { Smokers } \\
(\%)\end{array}$} & \multicolumn{2}{|c|}{$\begin{array}{c}\text { Diving } \\
\text { experience } \\
\text { (years) }\end{array}$} & \multirow{2}{*}{\multicolumn{2}{|c|}{$\begin{array}{c}\begin{array}{c}\text { Time in } \\
\text { saturation } \\
\text { (days) }\end{array} \\
\text { Median Range }\end{array}$}} & \multirow{2}{*}{\multicolumn{2}{|c|}{$\frac{\begin{array}{c}\text { Maximum depth } \\
(\mathrm{m})\end{array}}{\text { Median Range }}$}} \\
\hline & Mean & SD & & & & & Mean & SD & & & & \\
\hline $\begin{array}{l}\text { Deep divers } \\
\text { Reference divers }\end{array}$ & $\begin{array}{l}30.3 \\
31.1\end{array}$ & $\begin{array}{l}4.5 \\
4.5\end{array}$ & $\begin{array}{ll}180 & 7 \\
178 & 6\end{array}$ & $\begin{array}{l}78 \\
77\end{array}$ & $\begin{array}{l}8 \\
6\end{array}$ & $\begin{array}{l}21 \\
25\end{array}$ & $\begin{array}{l}8.3 \\
7.8\end{array}$ & $\begin{array}{l}4.5 \\
3.9\end{array}$ & $\begin{array}{l}192 \\
214\end{array}$ & $\begin{array}{r}27-360 \\
5-700\end{array}$ & $\begin{array}{l}142 \\
134\end{array}$ & $\begin{array}{l}85-500 \\
50-185\end{array}$ \\
\hline
\end{tabular}

Table 2. Base-line pulmonary function of the deep divers and the reference group at the time of entry into the study. (FVC $=$ forced vital capacity, $F E V_{1.0}=$ forced expiratory volume in $1 \mathrm{~s}, \mathrm{FEF}=$ forced expiratory flow rate at a certain percentage (figures in subscript) of the forced vital capacity, $\mathrm{PEF}=$ peak expiratory flow, $\mathrm{Tl}_{\mathrm{CO}}=$ transfer factor for carbon monoxide, $\mathrm{K}_{\mathrm{CO}}=$ transfer factor for carbon monoxide per unit alveolar volume)

\begin{tabular}{|c|c|c|c|c|c|c|c|c|c|c|c|c|c|c|c|c|c|c|}
\hline \multirow[t]{2}{*}{ Group } & \multicolumn{2}{|c|}{$\begin{array}{l}\text { FVC } \\
\text { (\% pre- } \\
\text { dicted) }\end{array}$} & \multicolumn{2}{|c|}{$\begin{array}{l}\mathrm{FEV}_{1.0} \\
\text { (\% pre- } \\
\text { dicted) }\end{array}$} & \multicolumn{2}{|c|}{$\begin{array}{l}\mathrm{FEF}_{25-75} \\
\text { (\% pre- } \\
\text { dicted) }\end{array}$} & \multicolumn{2}{|c|}{$\begin{array}{l}\mathrm{FEF}_{75-85} \\
\text { (\% pre- } \\
\text { dicted) }\end{array}$} & \multicolumn{2}{|c|}{$\begin{array}{l}\mathrm{FEF}_{50} \\
\text { (\% pre- } \\
\text { dicted) }\end{array}$} & \multicolumn{2}{|c|}{$\begin{array}{l}\mathrm{FEF}_{75} \\
\text { (\% pre- } \\
\text { dicted) }\end{array}$} & \multicolumn{2}{|c|}{$\begin{array}{c}\text { PEF } \\
\text { (\% pre- } \\
\text { dicted) }\end{array}$} & \multicolumn{2}{|c|}{$\begin{array}{c}\mathrm{Tl}_{\mathrm{co}} \\
\text { (\% pre- } \\
\text { dicted) }\end{array}$} & \multicolumn{2}{|c|}{$\begin{array}{c}\mathrm{K}_{\mathrm{co}} \\
\text { (\% pre- } \\
\text { dicted) }\end{array}$} \\
\hline & Mean & SD & Mean & $\mathrm{SD}$ & Mean & SD & Mean & SD & Mean & SD & Mean & SD & Mean & $S D$ & Mean & SD & Mean & SD \\
\hline $\begin{array}{l}\text { Deep divers } \\
\text { Reference divers }\end{array}$ & $\begin{array}{l}106 \\
104\end{array}$ & $\begin{array}{l}10 \\
10\end{array}$ & $\begin{array}{r}101 \\
97\end{array}$ & $\begin{array}{l}10 \\
11\end{array}$ & $\begin{array}{l}85^{*} \\
82^{*}\end{array}$ & $\begin{array}{l}17 \\
19\end{array}$ & $\begin{array}{l}80^{*} \\
75^{\star}\end{array}$ & $\begin{array}{l}15 \\
19\end{array}$ & $\begin{array}{l}84^{*} \\
81^{\star}\end{array}$ & $\begin{array}{l}16 \\
17\end{array}$ & $\begin{array}{l}76^{*} \\
72^{*}\end{array}$ & $\begin{array}{l}18 \\
21\end{array}$ & $\begin{array}{r}102 \\
99\end{array}$ & $\begin{array}{l}14 \\
17\end{array}$ & $\begin{array}{l}107 \\
104\end{array}$ & $\begin{array}{l}12 \\
13\end{array}$ & $\begin{array}{r}100 \\
97\end{array}$ & $\begin{array}{l}13 \\
15\end{array}$ \\
\hline
\end{tabular}

$* P<0.05$, significantly different from the predicted value. 
There were no differences between the deep divers and the referents in their reporting of respiratory infections or respiratory symptoms. Abnormal breathlessness on exertion or nonproductive coughing in the week following an ordinary saturation dive was reported by seven of the deep divers and ten of the reference divers, but no persistent pulmonary symptoms were reported in either group. The divers' smoking habits did not change, and there were no cases of decompression sickness during the observation period.

Dynamic lung volumes and flows were measured by at least three satisfactory forced expiratory maneuvers from the total lung capacity in the sitting position. The $\mathrm{FVC}, \mathrm{FEV}_{1.0}$, and peak expiratory flow rate (PEF) were taken as the highest readings obtained. $\mathrm{FEF}_{25-75}, \mathrm{FEF}_{75-85}, \mathrm{FEF}_{50}$, and $\mathrm{FEF}_{75}$ were taken as the highest readings from flow-volume loops not differing by more than 5\% from the highest FVC (11). Transfer factor for carbon monoxide $\left(\mathrm{Tl}_{\mathrm{CO}}\right)$ was measured by the single-breath holding method (11). Effective alveolar volume $\left(\mathrm{V}_{\mathrm{A}}\right)$ was measured simultaneously by helium dilution, and the transfer of carbon monoxide per unit of alveolar volume $\left(\mathrm{K}_{\mathrm{Co}}\right)$ was calculated. Static lung volumes were measured with the multibreath nitrogen washout technique from the functional residual capacity (FRC). In combination with the measurements of expiratory reserve volume (ERV) and inspiratory vital capacity (IVC), the total lung capacity (TLC) and residual volume (RV) were calculated. The closing volume (CV) and the slope of phase III of the single-breath oxygen test $\left(\Delta-\mathrm{N}_{2}\right)$ were also measured (12). All of the measurements were taken on a 1000 IV Computerized Pulmonary Function Laboratory (Gould Inc, Dayton, Ohio, United States). Volume and test gas calibrations were done before each test with the instrument's automatic dynamic calibration procedure, and the volume calibration was verified with a calibrated syringe both before and after each test (Gould calibration syringe $3.00 \mathrm{I}$, Gould Inc). The same instrument and calibration syringe were always used. The results were corrected to conditions of body temperature and pressure saturated with water vapor (BTPS).

The measurements were taken in the morning at least $2 \mathrm{~h}$ after breakfast without tea or coffee and with no smoking for $2 \mathrm{~h}$ before the measurements. At the time of the examination at least four weeks had elapsed since the last saturation dive. The dynamic lung volumes and flows and $\mathrm{Tl}_{\mathrm{CO}}$ of all of the divers were measured on every occasion. Static lung volumes, $\mathrm{CV}$ and $\Delta-\mathrm{N}$, were measured for 18 deep divers only, before and one year after the deep dive. For FVC, $\mathrm{FEV}_{1.0}, \mathrm{FEF}_{25-75}$, and $\mathrm{Tl}_{\mathrm{Co}}$, the predicted values of Gulsvik (13) and Gulsvik et al (14) were used; these values are based on cross-sectional surveys of asymptomatic subjects in a general population. For $\mathrm{FEF}_{75-85}, \mathrm{FEF}_{50}$, and $\mathrm{FEF}_{75}$ the predicted values were taken from our previous study of divers' lung function, which included a matched reference group (4), as updated predicted values for the general Scandinavian population are not available. All of the subjects gave their informed consent, and the protocol for the medical and physiological monitoring of the deep dives had been approved by the Regional Ethical Review Committee.

All of the results are given as means and standard deviations or medians and ranges. The individual rate of change of the lung function variables was calculated as the annual change between observations. The two-tailed t-test was used for comparing the deep divers with the referents and for comparing the determined values with the predicted values. A P-value of less than 0.05 was considered to be significant, but, when multiple comparisons were made, the Bonferroni correction method was used for adjusting the significance level.

\section{Results}

The mean annual reduction in $\mathrm{FEV}_{1.0}$ in all divers $(\mathrm{N}=52)$ over the whole observation period was 82 (SD 61) $\mathrm{ml} \cdot$ year $^{-1}$, which was significantly higher than the predicted annual loss of $34 \mathrm{ml} \cdot$ year $^{-1}$ $(\mathrm{P}<0.001)(13)$. There were no significant changes in FVC over the observation period. The control divers had a mean annual reduction in $\mathrm{FEV}_{1.0}$ of 35 (SD 80) $\mathrm{ml} \cdot$ year $^{-1}$ which was not different from the predicted value. The deep divers, on the other hand, showed a reduction of $210(\mathrm{SD} 84) \mathrm{ml}(\mathrm{P}<0.001)$ in $\mathrm{FEV}_{10 .}$ in the first year after the deep dive. Thereafter the annual reduction in $\mathrm{FEV}_{1.0}$ was 28 (SD 62) $\mathrm{ml} \cdot$ year $^{-1}$, which was not significantly different from the corresponding reduction of the reference divers or from the predicted value (figure 1 ). The forced expiratory flow rates at given fractions of the FVC expired showed changes similar to those of the $\mathrm{FEV}_{1,0}$, with a significant reduction in the first year after the deep dive (table 3). In the referents the rate of change in $\mathrm{FEF}_{75}$ was larger than predicted $(\mathrm{P}<0.02)$, whereas in the deep divers one year after the deep dive and thereafter the rates of change in the maximal expiratory flow rates did not differ from those of the reference divers or the predicted values. The PEF did not show any significant changes.

The deep divers had a reduction of 0.34 (SD 0.71) $\mathrm{mmol} \cdot \mathrm{min}^{-1} \cdot \mathrm{kPa}^{-1}$ in $\mathrm{Tl}_{\mathrm{co}}$ in the first year after the deep dive, and thereafter the annual reduction in $\mathrm{Tl}_{\mathrm{CO}}$ was 0.19 (SD 0.87) $\mathrm{mmol} \cdot \mathrm{min}^{-1} \cdot \mathrm{kPa}^{-1} \cdot$ year $^{-1}$, which was not significantly different from the 0.10 (SD 0.78) $\mathrm{mmol} \cdot \mathrm{min}^{-1} \cdot \mathrm{KPa}^{-1} \cdot$ year-1 of the reference divers or the predicted annual loss of 0.06 $\mathrm{mmol} \cdot \min ^{-1} \cdot \mathrm{kPa}^{-1} \cdot$ year ${ }^{-1}$. There was no significant change in $\mathrm{V}_{\mathrm{A}}$ in the referents or the deep divers, the changes in $\mathrm{K}_{\mathrm{CO}}$ therefore being similar to the changes in $\mathrm{Tl}_{\text {co }}$ (table 3 ). There was a small increase in $\mathrm{CV}$ $(\mathrm{P}<0.01)$ one year after the deep dive. TLC, FRC, $\mathrm{RV}$, and $\Delta-\mathrm{N}_{2}$ did not show any significant changes (table 4). 

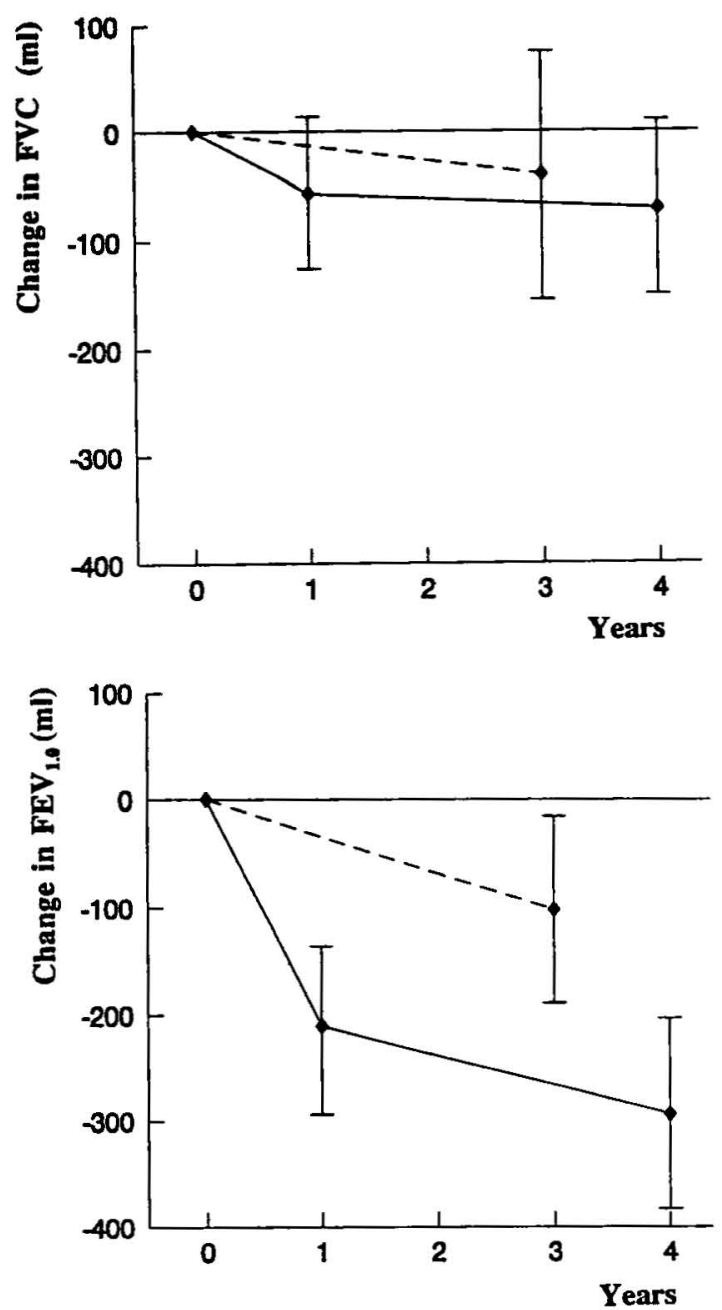

Figure 1. Change in forced vital capacity (FVC) and forced expiratory volume in $1 \mathrm{~s}\left(\mathrm{FEV}_{10}\right)$ in the deep divers $(\longrightarrow)$ one and four years after a deep saturation dive and in reference divers $(--)$. The mean reductions in FVC and $\mathrm{FEV}_{1.0}$ and their standard deviations are shown.

\section{Discussion}

The results showed that in the first year after the deep dive, there were significant reductions in $\mathrm{FEV}_{\mathrm{t}, 0}$ and forced expiratory flow rates that did not recover over the following three years of observation. There were no significant differences between the deep divers and reference divers at the time of entry into the study, and there were no obvious respiratory infections or other exceptional activities during the observation period that could explain the differences between the two groups of divers. Except for the deep dive, there were no significant differences in the diving exposure of the two groups during the observation periods.

The annual reduction in $\mathrm{FEV}_{1.0}$ in the deep divers one year after the deep dive and thereafter did not differ from that of saturation divers working in the North Sea or from the predicted annual reduction. The predicted annual reduction in $\mathrm{FEV}_{1.0}$ was, however, based on the results of a cross-sectional study. The majority of such studies report an annual reduction of $25-35 \mathrm{ml} \cdot$ year $^{-1}$ in $\mathrm{FEV}_{1.0}(11)$ on the basis of linear regression models of cross-sectional data of healthy populations $20-70$ years of age. Because of the age cohort effect (15), and because the decline in $\mathrm{FEV}_{10}$ may not start until the age of $25-30$ years, the predicted values may have been overestimated in the age range of our divers. There was no significant change in FVC over the observation period. It has been suggested in earlier studies that adaptation to the hyperbaric environment with its increased gas density and thereby increased work of breathing may result in an increase in FVC (5-7). This phenomenon could explain the relatively high FVC of the divers and the disproportionate elevation of the $\mathrm{FEV}_{1,0}$. For the relatively well-experienced divers in this study, no increase in FVC was demonstrated, neither immediately after the deep experimental dive

Table 3. Rate of change $(\Delta)$ in the lung function variables for the deep divers and the reference divers compared with the predicted rates of change $(4,13,14)$. ( $F V C=$ forced vital capacity, $F E V_{10}=$ forced expiratory volume in $1 \mathrm{~s}, F E F=$ forced expiratory flow rate at a certain percentage (figures in subscript) of the forced vital capacity, PEF $=$ peak expiratory flow, $\mathrm{TI}_{\mathrm{co}}=$ transfer factor for carbon monoxide, $\mathrm{K}_{\mathrm{CO}}=$ transfer factor for carbon monoxide per unit of alveolar volume)

\begin{tabular}{|c|c|c|c|c|c|c|c|}
\hline & \multicolumn{4}{|c|}{ Deep divers ${ }^{a}$} & \multirow{2}{*}{\multicolumn{2}{|c|}{$\begin{array}{l}\text { Reference divers } \\
\text { (rate of change } \\
\text { between base-line and } \\
\text { 3-year examinations) }\end{array}$}} & \multirow{3}{*}{ Predicted } \\
\hline & \multicolumn{2}{|c|}{$\begin{array}{c}\text { Rate of change } \\
\text { between base-line and } \\
1 \text {-year examinations }\end{array}$} & \multicolumn{2}{|c|}{$\begin{array}{c}\text { Rate of change } \\
\text { between } 1 \text {-year and } \\
\text { 4-year examinations }\end{array}$} & & & \\
\hline & Mean & SD & Mean & SD & Mean & SD & \\
\hline 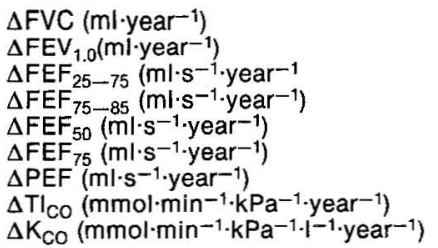 & $\begin{array}{l}-56 \\
-210^{c} \\
-323^{c} \\
-181^{c} \\
-346^{c} \\
-223^{c} \\
-32 \\
-0.34 \\
-0.028\end{array}$ & $\begin{array}{l}77 \\
84 \\
184 \\
102 \\
197 \\
115 \\
232 \\
0.71 \\
0.076\end{array}$ & $\begin{array}{l}-8 \\
-28 \\
-87 \\
-56 \\
-83 \\
-79 \\
-10 \\
-0.19 \\
-0.012\end{array}$ & $\begin{array}{l}83 \\
62 \\
201 \\
92 \\
193 \\
106 \\
253 \\
0.87 \\
0.090\end{array}$ & $\begin{array}{l}-12 \\
-35 \\
-104 \\
-69 \\
-116 \\
-101 \\
41 \\
-0.10 \\
-0.009\end{array}$ & $\begin{array}{l}102 \\
80 \\
226 \\
106 \\
192 \\
112^{\mathrm{d}} \\
240 \\
0.78 \\
0.083\end{array}$ & $\begin{array}{l}-29 \\
-34 \\
-43 \\
-40 \\
-38 \\
-47 \\
-20 \\
-0.06 \\
-0.008\end{array}$ \\
\hline
\end{tabular}

a Number of divers was 24 in one-year examination and 22 in four-year examination.

b Number of divers was 28 .

c $P<0.001$; significantly different from the predicted and referents' value.

d $\mathrm{P}<0.02$; significantly different from predicted. 
(9) nor at the end of the follow-up period. The crosssectional study in which these divers were included did not show any correlation between FVC and diving exposure, and there were no differences in the static lung volumes between the divers and a matched reference group (4). The results are therefore consistent with the development of airflow limitation in divers, and the characteristics of their lung function cannot be explained by adaptation or selection. The larger-than-predicted rate of change in $\mathrm{FEF}_{75}$ among the reference divers and the increase in $\mathrm{CV}$ in the deep divers are also in agreement with the development of airflow limitation.

In contrast to our previous cross-sectional study of divers' lung function (4) and the studies of pulmonary function immediately after deep dives $(9$, 10 ), there was no significant reduction in $\mathrm{Tl}_{\mathrm{CO}}$ in this investigation. The mean reduction in $\mathrm{Tl}_{\mathrm{CO}}$ immediately after the deep saturation dives was $10.6 \%$ or 1.24 (SD 0.87) $\mathrm{mmol} \cdot \mathrm{min}^{-1} \cdot \mathrm{kPa}^{-1}(\mathrm{P}<0.001)$, and 0.39 (SD 0.78) $\mathrm{mmol} \cdot \mathrm{min}^{-1} \cdot \mathrm{kPa}^{-1}(\mathrm{P}<0.05)$ one month later. There were, on the other hand, no changes in the $\mathrm{FEV}_{1.0}$ or maximal expiratory flow rates immediately after or one month after the deep dives. The changes in dynamic lung volumes and flows must therefore have taken place later than one month after the deep dive and may therefore not be related to the deep dive at all. There was, however, a significant increase in TLC and FRC immediately after the deep dives, and the increase could have compensated for a real reduction in the maximal expiratory flow rates since these measurements are related to the fraction of FVC expired and not to absolute lung volume.

Several factors may be involved in the development of airflow limitation in divers. In saturation diving, the partial pressure of oxygen is usually elevated to $40-60 \mathrm{kPa}$ to ensure oxygenation and facilitate inert gas elimination during decompression. Oxygen has well-established acute toxic effects on the lungs (16), and in an animal study by Riley et al (17) it was shown that four to six weeks after exposure to hyperoxia loss of pulmonary elastic tissue and reduced pulmonary recoil pressure occur. These findings are consistent with the development of an emphysematous lesion. Venous gas microemboli generated during decompression are common, even in the absence of clinical decompression sickness (18), and can induce pulmonary inflammatory lesions and gas exchange abnormalities $(19,20)$. This effect can be potentiated by hyperoxia since oxygen radicals are involved in the inflammatory reactions induced by gas microembolism (19). The exposure to factors such as cumulative hyperoxic exposure, cumulative hyperbaric exposure, time in saturation, and time in decompression were all interrelated and correlated with the maximal pressure to which the deep divers were exposed during the observation period. We were therefore not able to ascribe the changes in the
Table 4. Static lung volumes, closing volume, and slope of phase III of the single-breath oxygen test before and one year after a deep saturation dive ( $N=18$ ). (IVC $=$ inspiratory vital capacity, $T L C=$ total lung capacity, $F R C=$ functional residual capacity, $\mathrm{RV}=$ residual volume, $\mathrm{CV}=$ closing volume, $\mathrm{VC}=$ vital capacity, $\Delta-\mathrm{N}_{2}=$ slope of phase III of the single-breath oxygen test)

\begin{tabular}{|c|c|c|c|c|}
\hline & \multicolumn{2}{|c|}{ Before dive } & \multicolumn{2}{|c|}{$\begin{array}{l}\text { One year after } \\
\text { dive }\end{array}$} \\
\hline & Mean & $\mathrm{SD}$ & Mean & $S D$ \\
\hline $\begin{array}{l}\text { IVC (I) } \\
\text { TLC (I) } \\
\text { FRC (I) } \\
\text { RV (I) } \\
\text { CV }(\% \text { of VC) } \\
\Delta-N_{2}(\%)\end{array}$ & $\begin{array}{c}6.21 \\
7.95 \\
3.94 \\
1.68 \\
11.2 \\
0.71\end{array}$ & $\begin{array}{l}0.54 \\
0.86 \\
0.83 \\
0.35 \\
1.8 \\
0.10\end{array}$ & $\begin{array}{c}6.16 \\
8.04 \\
3.82 \\
1.86 \\
13.7^{\star \star *} \\
0.77\end{array}$ & $\begin{array}{l}0.58 \\
0.74 \\
0.74 \\
0.31 \\
3.1 \\
0.12\end{array}$ \\
\hline
\end{tabular}

* $P<0.01$, significantly different from before deep dive.

lung function variables to more specific exposure factors than maximal pressure, which was used as the determinant differentiating between the two groups of divers.

\section{Acknowledgments}

This work was supported by Norsk Hydro A/S, Statoil, and the Royal Norwegian Council for Scientific and Industrial Research (NTNF).

\section{References}

1. Crosbie WA, Reed JW, Clarke MC. Functional characteristics of the large lungs found in commercial divers. J Appl Physiol 1979;46:639-45.

2. Davey IS, Cotes JE, Reed JW. Relationship of ventilatory capacity to hyperbaric exposure in divers. J Appl Physiol 1984;56:1655-8.

3. Watt S. Effect of commercial diving on ventilatory function. Br J Ind Med 1985;42:59-62.

4. Thorsen E, Segadal K, Kambestad B, Gulsvik A. Divers' lung function: small airways disease? Br J Ind Med 1990;47:519--23.

5. Cotes JE, Davey IS, Reed JW, Rooks M. Respiratory effects of a single saturation dive to $300 \mathrm{~m}$. Br J Ind Med 1987;44:76-82.

6. Smith RM, Hong SK, Dressendorfer RH, Dwyer HJ, Hayashi E, Yelverton C. Hana Kai II: a 17 day dry saturation dive at 18.6 ATA: cardiopulmonary functions. Undersea Biomed Res 1977;4:267—81.

7. Yamasaki M, Taya Y, Fujiie K, Seki K, Sasaki T, Nakayama $\mathrm{H}$. Effects of a simulated saturation dive to 31 ATA on pulmonary function. Ann Physiol Anthropol 1986;5:191-6.

8. Bouhuys A, Beck GI. Large lungs in divers? J Appl Physiol 1979;47:1136.

9. Thorsen E, Segadal K, Myrseth E, Påsche A, Gulsvik A. Pulmonary mechanical function and diffusion capacity after deep saturation dives. Br J Ind Med 1990; $47: 242-7$

10. Thorsen E, Hjelle J, Segadal K, Gulsvik A. Exercise tolerance and pulmonary gas exchange after deep saturation dives. J Appl Physiol 1990;68:1809-14.

11. Quanjer PH, ed. Standardized lung function testing. Bull Eur Physiopathol Respir 1983;19 suppl 5:7—10.

12. National Heart and Lung Institute. Suggested stand- 
ardised procedures for closing volume determinations (nitrogen method). Bethesda, MD: Division of Lung Diseases, National Heart and Lung Institute, 1973.

13. Gulsvik, A. Obstructive lung disease in an urban population. Oslo: Reprografisk Industri, 1979:88-120.

14. Gulsvik A, Bakke P, Humerfelt S, Omenaas E, Tosteson T, Weiss ST, et al. Single breath transfer factor for carbon monoxide in an asymptomatic population of never smokers. Thorax 1992;47:167-73.

15. Burrows B, Lebowitz MD, Camilli AE, Knudson RJ. Longitudinal changes in forced expiratory volume in one second in adults. Am Rev Respir Dis 1986;133: $974-80$.

16. Clark JM. Oxygen toxicity. In: Bennett PB, Elliott DH, ed: The physiology and medicine of diving. London: Balliere Tindall, 1982:200-38.

17. Riley DJ, Cramer MJ, Kerr JS, Chae CU, Yu SY, Berg
RA. Damage and repair of lung connective tissue in rats exposed to toxic levels of oxygen. Am Rev Respir Dis 1987; 135:441-7.

18. Spencer MP, Clark HF. Precordial monitoring of pulmonary gas embolism and decompression sickness. Aerosp Med 1972;43:762-7.

19. Flick MR, Milligan SA, Hoeffel JM, Goldstein IM. Catalase prevents increased lung vascular permeability after micro-embolization in sheep. J Appl Physiol 1988;64:929-35.

20. Hlastala MP, Robertson HT, Ross BK. Gas exchange abnormalities produced by venous gas emboli. Respir Physiol 1979;36:1-17.

Received for publication: 23 June 1992 